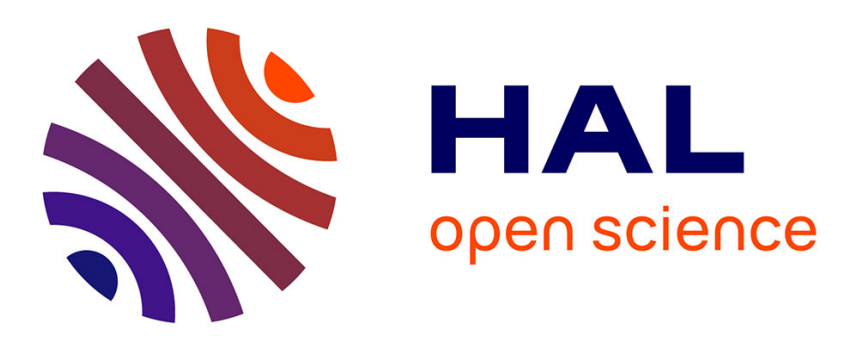

\title{
A novel index of land use intensity for organic and conventional farming of Mediterranean cereal fields
} Armengot, José-María, José Blanco-Moreno, Bassa, Chamorro, F. Sans

\section{To cite this version:}

Armengot, José-María, José Blanco-Moreno, Bassa, Chamorro, et al.. A novel index of land use intensity for organic and conventional farming of Mediterranean cereal fields. Agronomy for Sustainable Development, 2011, 31 (4), pp.699-707. 10.1007/s13593-011-0042-0 . hal-00930514

\section{HAL Id: hal-00930514 https://hal.science/hal-00930514}

Submitted on 1 Jan 2011

HAL is a multi-disciplinary open access archive for the deposit and dissemination of scientific research documents, whether they are published or not. The documents may come from teaching and research institutions in France or abroad, or from public or private research centers.
L'archive ouverte pluridisciplinaire HAL, est destinée au dépôt et à la diffusion de documents scientifiques de niveau recherche, publiés ou non, émanant des établissements d'enseignement et de recherche français ou étrangers, des laboratoires publics ou privés. 


\title{
A novel index of land use intensity for organic and conventional farming of Mediterranean cereal fields
}

\author{
Laura Armengot • Laura José-María • \\ José M. Blanco-Moreno • Montserrat Bassa • \\ Lourdes Chamorro $\cdot$ F. Xavier Sans
}

Accepted: 21 June 2011 / Published online: 15 July 2011

(C) INRA and Springer Science+Business Media B.V. 2011

\begin{abstract}
The conservation of biodiversity in agroecosystems is closely related to land use. Intensive land use is considered to be a major cause of biodiversity loss. Most studies addressing the effect of land use intensity on biodiversity have compared organic and conventional systems. However, little is known about the heterogeneity of the management intensity within each farming system. We hypothesise that there is a gradient of land use between and within the farming systems and that an index of management intensity is more useful than the farming system for evaluating the effects of the management practices on weed flora. In this study, 18 pairs of organic and conventional cereal fields were selected in northeastern Spain. The farmers were interviewed to gather information on the management practices performed. We selected the five following variables from these interviews: nitrogen inputs, crop diversity, weed control, seed origin and cereal ratio. We used principal components analysis to create a new management index. Weed species richness was recorded in 10 field pairs before crop harvest. Our results showed that the index values displayed huge variation within each farming system. Index values of conventional fields varied between -0.01 and 1.00 , whereas within organic ones the values ranged from -1.19 to 0.18 . The index better explained weed species richness than did the farming system. The index values demonstrate the existence of a land use intensity gradient, which indicates that it is an oversimplification to always equate organic farming with low intensity management. Here, we also prove that this new
\end{abstract}

L. Armengot $(\varangle) \cdot$ L. José-María · J. M. Blanco-Moreno

M. Bassa $\cdot$ L. Chamorro $\cdot$ F. X. Sans

Departament de Biologia Vegetal, Facultat de Biologia,

Universitat de Barcelona,

Av. Diagonal, 645,

08028 Barcelona, Catalonia, Spain

e-mail: larmengot@ub.edu index is more appropriate for evaluating the effects of management practices on weed species richness than the classical organic-conventional dichotomy.

Keywords Crop rotation - Land use intensity gradient . Nitrogen inputs · Seed origin · Weed control intensity. Weed species richness

\section{Introduction}

High intensity land use, which is characterised by monoculture, intensive ploughing and high rates of mineral fertilisation and pesticides, has negative consequences on the environment. Among others, increased soil erosion, lower soil fertility, pollution of ground water and eutrophication of rivers and lakes are the main ecological problems reported (Matson et al. 1997). Intensification of land use has also been identified as a major cause of the current biodiversity decline in agroecosystems (Reidsma et al. 2006; Robinson and Sutherland 2002). For instance, arable weeds have suffered a severe decline over all Europe (Petit et al. 2011). This loss of weed diversity affects the delivery of ecosystems services and the support of animal diversity (Matson et al. 1997; Petit et al. 2011), which has developed concerns over the sustainability and environment consequences of the intensification of land use in agricultural systems. Hence, reliable methods for assessing the land use intensity of cropping systems are essential (Bockstaller et al. 2008). Such methods should allow the comparison of farms or regions and the implementation of adequate measures for species conservation strategies.

Most studies addressing the effect of land use intensity on farmland biodiversity have used a comparison of organic and conventional farms (Gibson et al. 2007; Hole et al. 2005). However, these comparisons are based on the 
assumption that agricultural practices, and consequently land use intensity, are well-differentiated between the farming systems and also fairly homogeneous within each system. Although there is evidence that conventional farming is usually more intensive than organic farming, there is little information regarding the variation in management intensity within each farming system (but see Rigby et al. 2001). Nevertheless, agricultural practices could differ significantly between farms. Accordingly, it is feasible to consider the existence of a gradient in land use intensity between and within the farming systems. For instance, for each farming system, the switch from intermittent to continuous cultivation and the specialisation of farms are trends associated with management intensification (Giller et al. 1997). As an example, in Catalonia (northeastern Spain), the percentage of fallow agricultural land and the number of mixed farms have considerably decreased over the last decades (Idescat 2010).

Accordingly, for a better assessment of land use intensity, it could be more accurate to focus on specific farming practices rather than on the classical organic-conventional dichotomy. In this sense, several approaches have been proposed to assess land use intensity (see Shriar 2000). Some authors have used the crop yield per unit of land, although that is highly variable between crops and could also be affected by interannual variability in rainfall. For example, yields under Mediterranean conditions usually depend more on the availability of water than on the intensity of farming practices (wheat yield and total mean rainfall in Catalonia; 2004, $3.9 \mathrm{t} \mathrm{ha}^{-1}, 541.9 \mathrm{~mm} ; 2006$, $2.6 \mathrm{t} \mathrm{ha}^{-1}, 436.7 \mathrm{~mm}$; Idescat 2010). Other studies quantify agricultural inputs related to land productivity, such as nitrogen fertilisation or the application of pesticides (Giller et al. 1997; Herzog et al. 2006; Reidsma et al. 2006; Rigby et al. 2001; Shriar 2000).

The objective of our study was to assess the land use intensity in organic and conventional dryland cereal fields in the Mediterranean region and its effects on weed flora. We hypothesise that: (1) there is a gradient of land use intensity between and within organic and conventional fields and (2) an index that summarises the information on several management practices is a more appropriate variable than each single management variable or the farming system (organic vs. conventional) in evaluating the land use intensity and its effects on weed diversity.

\section{Materials and methods}

\subsection{Study site}

This study was conducted in 2007 at 18 sites in Catalonia (northeastern Spain). The criterion for selecting the sites was the presence of farms that had been managed organically since at least 2001 (median=1996). The area studied covered approximately $100 \times 50 \mathrm{~km}$, extending from $1^{\circ} 05^{\prime}$ to $2^{\circ} 05^{\prime} \mathrm{E}$ and from $41^{\circ} 24^{\prime}$ to $42^{\circ} 05^{\prime} \mathrm{N}$. The mean altitude ( \pm standard error) was $542.4 \pm 40.0 \mathrm{~m}$ above sea level, and the climate was Mediterranean, with an annual average precipitation of $610.4 \pm 22.3 \mathrm{~mm}$ and temperature of $12.6 \pm 0.2^{\circ} \mathrm{C}$.

At each site, we selected one organic and one conventional farm. Their main economic activity was cereal production. From each farm, we selected one dryland cereal field. The organic and conventional fields were close, but not adjacent, to avoid the potential detrimental effects of the neighbouring agricultural practices, such as herbicide applications, on the organic fields. The fields were chosen to minimise differences in soil type and the major physiographic characteristics, such as slope, orientation, and size. Accordingly, fields shared similar area (conventional, $1.68 \pm 0.14$ ha, mean \pm standard error; organic, $1.35 \pm 0.12$ ha; Wilcoxon's paired tests within site, $P=0.99$ ) and perimeter measurements (conventional, $563.8 \pm 15.6 \mathrm{~m}$; organic, $534.0 \pm 28.2 \mathrm{~m} ; P=0.49$ ), and the soil was basic with a loamy-clayish texture. Both the conventional and organic farmers sowed cereals (winter wheat or barley) between September and October.

\subsection{Characterisation of farming practices}

Each farmer was interviewed to characterise his agricultural practices, such as crop rotation, tillage and fertilisation. The questions related to the selected field for the last 5 years, as information about the management from previous years was unreliable. All of the surveys were conducted by the same two people to standardise the interviews as much as possible.

We selected five management variables from the information obtained through the interviews: mean annual inputs of exogenous nitrogen, weed control intensity, cereal ratio, crop diversity, and seed origin (Table 1). Among other variables, the number of crops per season, soil tillage, field management after harvest, and sowing date were discarded because they were highly homogeneous for all fields and therefore failed to provide relevant information.

\subsection{Land use intensity index}

We applied a data reduction technique (principal components analysis, PCA) to the selected variables to obtain our index of land use intensity (hereafter LUI index). PCA is a commonly used data-reduction method that allows the capture of most of the variation of the original data in a few new variables. We used the scores of the first component of the PCA as an objective measure of land 
Table 1 Variables included in the land use intensity index

\begin{tabular}{|c|c|c|}
\hline Variables & Definition & Justification \\
\hline $\begin{array}{l}\text { Nitrogen } \\
\text { inputs }\end{array}$ & $\begin{array}{l}\mathrm{N} \mathrm{kg} \mathrm{ha}^{-1} \text {. The mean annual input of exogenous } \\
\mathrm{N} \text { per ha and year. This variable was calculated } \\
\text { from information from the farmers about the quantity } \\
\text { and type of fertiliser, using local tables of } \mathrm{N} \text { content }\end{array}$ & $\begin{array}{l}\text { High rates of nitrogen fertilisation increase eutrophication } \\
\text { of the soil and the risk of nitrate leaching, which could } \\
\text { negatively affect weed species diversity (Billeter et al. 2008; } \\
\text { Firbank et al. 2008; Kleijn et al. 2009) }\end{array}$ \\
\hline $\begin{array}{l}\text { Weed } \\
\text { control }\end{array}$ & $\begin{array}{l}\text { The intensity of weed control }(0, \text { no weed control; } 1 \text {, } \\
\text { weed harrowing with long-flex spring tines; } 2 \text {, } \\
\text { herbicide). Only one application of herbicide (against } \\
\text { broad- and grass weed species) per year (in winter) } \\
\text { was recorded in the conventional fields. Similarly, } \\
\text { mechanical weed control in organic fields was also } \\
\text { performed once a year }\end{array}$ & $\begin{array}{l}\text { Weed control can reduce the diversity of flora and their } \\
\text { associated fauna. Weed control in the organic and the } \\
\text { conventional fields was weighted differently because of } \\
\text { the greater efficiency of chemical control (Lundkvist 2009) }\end{array}$ \\
\hline $\begin{array}{r}\text { Cereal } \\
\text { ratio }\end{array}$ & $\begin{array}{l}\text { The percentage of years within a rotational scheme } \\
\text { that the field was sown with cereals }\end{array}$ & $\begin{array}{l}\text { Cereal monoculture changes soil microorganisms and weed flora, } \\
\text { depletes essential soil nutrients and can encourage persistent } \\
\text { pests and diseases (Karlen et al. 1994; Stevenson et al. 1997) }\end{array}$ \\
\hline $\begin{array}{l}\text { Crop } \\
\text { diversity }\end{array}$ & $\begin{array}{l}\text { The number of different families of crops sown within } \\
\text { the last five years: cereals, legumes, tubers, etc. }\end{array}$ & $\begin{array}{l}\text { The potential effects of crop rotation depend upon the choice } \\
\text { of crops grown and their sequence within the rotation. Crop } \\
\text { diversity supports biodiversity at different levels (soil } \\
\text { microorganisms, weeds, insects, etc.). It can improve soil } \\
\text { structure and fertility by alternating deep-rooted and shadow } \\
\text { rooted crops (Karlen et al. 1994) }\end{array}$ \\
\hline $\begin{array}{l}\text { Seed } \\
\text { origin }\end{array}$ & $\begin{array}{l}\text { Use (1) or no use }(0) \text { of commercial seeds. The re-use of } \\
\text { cereal seeds could be a source of weed seeds, as re- } \\
\text { used seeds were usually much more infested by them } \\
\text { than were commercial cereal seeds (personal observation) }\end{array}$ & $\begin{array}{l}\text { Improvements in seed cleaning techniques have reduced } \\
\text { and threatened the existence of some weed species } \\
\text { (e.g., Holzner 1982) }\end{array}$ \\
\hline
\end{tabular}

use intensity for each field because it accounts for the maximum amount of variance. Thus, the PCA should allow us to summarise in only one variable (LUI index) the information about the selected management practices (mean nitrogen inputs, weed control intensity, cereal ratio, crop diversity, and seed origin). Therefore, the LUI index represents a global land use intensity measure for each field because it includes information about all of the selected management variables. As the management variables had different units, they were standardised by subtracting the lowest value of each variable from each value of that variable and dividing by the range. Hence, all of the variables ranged from 0 to 1 . We explored the relationships among the management variables and between them and the LUI index using a Spearman's correlation analysis for continuous variables and using a Wilcoxon rank-sum test for the categorical variable (seed origin).

\subsection{Relating weed flora to land use intensity}

We used the developed LUI index, its constituent management variables and the farming system (organic vs. conventional) as proxies for land use intensity to assess their effects on weed flora. We evaluated 10 pairs of organic and conventional cereal fields that were randomly selected from among the 18 sites. The weed sampling was conducted in June by counting weed species in four $2 \times 2 \mathrm{~m}$ plots randomly placed in the centre of each field. Weed species richness was selected as a proxy for weed diversity because of its simplicity and sensitivity to agricultural intensification (Guerrero et al. 2010). Moreover, it has been the component of diversity most often considered in studies addressing the effect of agricultural intensification on weed flora.

The observed variance in weed species richness was analysed using mixed models. Mixed models account for nested sampling designs by using random effects. We considered each site, with one organic and one conventional field, as a block. The between-site (or between-block) variation around the average model (for all sites) can be considered to be a random effect. Several models were fitted, each with a different proxy for land use intensity as a fixed effect: the LUI index, the farming system, mean annual inputs of exogenous nitrogen, weed control intensity, cereal ratio, crop diversity, or seed origin. To ease comparison among the models, all variables were coded to test for the effects of increasing levels of agricultural intensity. Categorical variables were compared by orthogonal contrasts and continuous variables were standardised to have a mean of zero and standard deviation of one. The adequacy of the models was assessed through the normality and unbiasedness of residuals and through the predictive power of the model. We performed the same analysis for the organic and conventional fields separately through linear models. The analysis of the conventional fields did not include the model with the factor 'weed control intensity' as it had the same value for all of the conventional farmers. 
We evaluated these models using the methods described by Burnham and Anderson (2002). This approach compares the fit of the models using the Akaike's Information Criterion (AIC), which is proportional to the likelihood of the model and the number of parameters used to generate it. We computed the AIC corrected for small sample size (AICc) value for each model. The difference in AICc values between models $\left(\Delta_{i}=\mathrm{AICc}_{i}-\operatorname{minAICc}\right)$ is a measure of the fit of each model relative to the best model (the model with the minimum AICc value) and indicates the relative support for the different models. A $\Delta_{i}<2$ suggests substantial evidence for the model; values between 3 and 7 indicate that the model has considerably less support, whereas a $\Delta_{i}>$ 10 indicates that the model is very unlikely (Burnham and Anderson 2002). The Akaike weight $\left(w_{i}\right)$ of each model indicates the probability of it being the best model among the candidate models. We also computed the $95 \%$ confidence intervals of each variable to evaluate their respective contributions to the explanatory power of the model. We carried out statistical analyses using R 2.7.1 (R Development Core Team 2008), with the package "Ime4" (Bates et al. 2008) for mixed models.

\section{Results and discussion}

\subsection{Farming practices}

Overall, the organic and conventional fields differed largely in their management practices. All of the conventional farmers applied broad-leaf and grass herbicides annually, but only six out of the 17 organic farmers controlled weeds mechanically (weed harrowing; Table 2). Most of the conventional farmers (16/18) sowed cereal every year, alternating wheat and barley, whereas organic farmers performed more complex rotations involving different crop families. Farmers who re-used their own cereal seeds usually cleaned them before sowing. However, these seeds

Table 2 Overall agricultural practices for each organic and conventional field

\begin{tabular}{|c|c|c|c|c|c|c|c|c|c|c|}
\hline \multirow[t]{2}{*}{ Site } & \multicolumn{5}{|l|}{ Organic } & \multicolumn{5}{|c|}{ Conventional } \\
\hline & $\begin{array}{l}\text { Weed } \\
\text { control }\end{array}$ & Rotation & $\begin{array}{l}\text { Source of } \\
\text { fertilisation }\end{array}$ & $\begin{array}{l}\text { Fertilisation } \\
\left(\mathrm{kg} \mathrm{N} \mathrm{ha}^{-1}\right)\end{array}$ & $\begin{array}{l}\text { Seed } \\
\text { origin }\end{array}$ & $\begin{array}{l}\text { Weed } \\
\text { control }\end{array}$ & Rotation & $\begin{array}{l}\text { Source of } \\
\text { fertilisation }\end{array}$ & $\begin{array}{l}\text { Fertilisation } \\
\left(\mathrm{kg} \mathrm{N} \mathrm{ha}^{-1}\right)\end{array}$ & $\begin{array}{l}\text { Seed } \\
\text { origin }\end{array}$ \\
\hline BAL & - & W-W-CK-W-VE & - & - & RU & $\mathrm{H}$ & W-B & $\mathrm{N}, \mathrm{PS}^{\mathrm{a}}$ & 74.4 & $\mathrm{C}$ \\
\hline BLA & - & B & - & - & RU & $\mathrm{H}$ & B & $\mathrm{N}$ & 232.8 & $\mathrm{C}$ \\
\hline $\mathrm{CAB}$ & - & $\mathrm{W}-\mathrm{W}-(\mathrm{O}+\mathrm{TS}+\mathrm{V})$ & - & - & RU & $\mathrm{H}$ & W-B & $\mathrm{BM}, \mathrm{N}, \mathrm{U}^{\mathrm{a}}$ & 80.0 & $\mathrm{C}$ \\
\hline CAL & - & W(+TU)-O-CK & $\mathrm{BM}$ & 36.0 & RU & $\mathrm{H}$ & B & $\mathrm{PS}, \mathrm{N}, \mathrm{BM}, \mathrm{HS}$ & 73.6 & RU \\
\hline CAR & WH & B-B-V-B-ON & PS, BM & 48.2 & $\mathrm{C}$ & $\mathrm{H}$ & W-B & $\mathrm{PS}^{\mathrm{a}}$ & 213.5 & $\mathrm{C}$ \\
\hline CAS & WH & B-B-O-CK-W & - & - & RU & $\mathrm{H}$ & B-B-PM & $\mathrm{N}$ & 200.0 & $\mathrm{C}$ \\
\hline ESP & WH & W-R-VE-T-H & $\mathrm{SM}, \mathrm{BM}$ & 105.0 & RU & $\mathrm{H}$ & W-B & $\mathrm{BN}, \mathrm{PS}, \mathrm{U}^{\mathrm{a}}$ & 228.4 & RU \\
\hline FRA & - & W-P-L-O-B & - & - & RU & $\mathrm{H}$ & W-B & $\mathrm{N}, \mathrm{PS}, \mathrm{U}^{\mathrm{a}}$ & 60.0 & RU \\
\hline MAL & - & $\mathrm{W}-(\mathrm{V}+\mathrm{O})$ & SM, HS & 38.3 & RU & $\mathrm{H}$ & $\mathrm{W}-(\mathrm{O}+\mathrm{V})-\mathrm{B}-\mathrm{O}$ & $\mathrm{N}$ & 58.3 & $\mathrm{C}$ \\
\hline MAN & & & & & & $\mathrm{H}$ & W-B & $\mathrm{PS}, \mathrm{HS}^{\mathrm{a}}$ & 195.0 & RU \\
\hline MAS & - & W-W-W-O & BM, HS & 44.2 & $\mathrm{C}$ & $\mathrm{H}$ & W & $\mathrm{PS}, \mathrm{N}^{\mathrm{a}}$ & 142.8 & $\mathrm{C}$ \\
\hline MOI & - & $\mathrm{W}-\mathrm{ON}-\mathrm{ON}-(\mathrm{V}+\mathrm{O})-\mathrm{B}$ & $\mathrm{BM}$ & 13.8 & RU & $\mathrm{H}$ & B-W-O & PS & 119.6 & RU \\
\hline MON & WH & W-B & PS, BM & 108.7 & RU & $\mathrm{H}$ & $\mathrm{B}$ & $\mathrm{PS}, \mathrm{N}^{\mathrm{a}}$ & 152.5 & $\mathrm{C}$ \\
\hline PIL & WH & B-TS-TS-CK-W & $\mathrm{BM}, \mathrm{RM}$ & 47.9 & RU & $\mathrm{H}$ & W-B & $\mathrm{PS}^{\mathrm{a}}$ & 190.7 & RU \\
\hline PGU & WH & W-BE-O-B-CK & $\mathrm{RM}^{\mathrm{a}}$ & 4.35 & RU & $\mathrm{H}$ & $\mathrm{B}$ & $\mathrm{N}, \mathrm{U}^{\mathrm{a}}$ & 107.6 & RU \\
\hline SUR & - & W-B-CK-W-B & $\mathrm{SM}$ & 23.4 & RU & $\mathrm{H}$ & W-B & $\mathrm{BM}, \mathrm{PS}, \mathrm{N}, \mathrm{U}^{\mathrm{a}}$ & 121.7 & $\mathrm{C}$ \\
\hline TAR & - & W-V-B-O-W & - & - & RU & $\mathrm{H}$ & W-B & PS & 145.9 & $\mathrm{C}$ \\
\hline VAL & - & B-O-O-B-P & SM & 18.8 & $\mathrm{C}$ & $\mathrm{H}$ & $\mathrm{B}$ & $\mathrm{PS}, \mathrm{U}^{\mathrm{a}}$ & 325.0 & $\mathrm{C}$ \\
\hline
\end{tabular}

Data refer to 5 years, from 2003 to 2007 . Weed control: $H$ herbicide application, $W H$ weed harrowing. Rotation: $B$ barley (Hordeum vulgare L.), $B E$ beans (Phaseolus vulgaris L.), CK chickpeas (Cicer arietinum L.), $H$ hemp (Cannabis sativa L.), L lentils (Lens culinaris Medik.), $O$ oats (Avena sativa L.), ON sainfoin (Onobrychis viciifolia Scop.), $P$ peas (Pisum sativum L.), PM common millet (Panicum miliaceum L.), $R$ ray-grass (Lolium sp.), $T$ triticosecale (Triticum L. $\times$ Secale L. hybrid), TS spelt (Triticum spelta L.), TU turnips (Brassica rapa L.), V common vetch (Vicia sativa L.), VE bitter vetch (Vicia ervilia (L.) Willd.), $W$ wheat (Triticum aestivum L.). Farmers repeat the rotation scheme when the number of crops is lower than five. Source of fertilisation: $B M$ bovine manure, $H S$ hen slurry, $N$ commercial nitrogen, $P S$ pig slurry, $R M$ rabbit manure, $S M$ ship manure, $U$ urea. Seed origin: $C$ commercial seeds, $R U$ re-use of own seeds. MAN organic field was discarded because of unreliable data

${ }^{\text {a }}$ Fertilisation is applied in the spring (otherwise it is applied only in autumn) 
were more infested by weeds than the commercial seeds (personal observation) and were a potential source of weed diversity for the field. The type of fertilisation and the frequency and the quantity of nitrogen applied varied greatly among farmers. Overall, the average amount of nitrogen added was higher among the conventional farmers (mean \pm standard error: $151.2 \pm 17.1$ and $30.5 \pm 8.4 \mathrm{~kg} \mathrm{ha}^{-1}$ for the conventional and organic farmers, respectively; Wilcoxon's paired tests within site: $P<0.001$; Table 2). Spring top-dressed fertilisers were used by some conventional farmers but by only one organic farmer. In addition, some organic farmers did not use external inputs to fertilise, relying only on crop rotation and green manure (Table 2). One organic field was discarded because we could not obtain trustworthy data.

To our knowledge, this is the first study to assess land use intensity in Mediterranean conditions. The interviews revealed that management under Mediterranean conditions displays huge differences from that of northern and central Europe (Herzog et al. 2006). For instance, all of the conventional farmers interviewed applied herbicide only once a year (in January or February), and they did not use retardants or insecticides in cereal fields. Similarly, organic farmers who had a weed harrow used it only once a year. Moreover, most farmers grew only one crop per year due to the long period of water stress after crop harvest.

There were high correlations among agricultural practices (Table 3). This is an inherent characteristic of the system under study, implying that several practices often co-occurred. For instance, farmers who applied high amounts of nitrogen fertilisation usually performed simple rotations, used commercial seeds and relied on herbicides. In contrast, we found that low levels of nitrogen fertilisation were associated with complex rotations, the re-use of seeds and the absence of herbicides.

\subsection{Land use intensity index}

Developing an index often involves weighting each selected variable (Decaëns and Jiménez 2002; Herzog et al. 2006; Mas and Dietsch 2003; Rigby et al. 2001) because it is unlikely that all variables have equal effects. However, it is sometimes difficult to find clear criteria that justify weighting some variables more than others. Weighting variables is a key step in the development of an index, as the final values will be determined by the weights of the component variables. Consequently, to avoid the subjectivity of this process, we used a PCA of the five selected management variables to obtain a land use intensity value for each field. The first two components accounted for $86.45 \%$ of variance, and the first component (PC1) explained $64.51 \%$. Given that the PC1 accounted for most of the variability in the data, we used it as an index of land use intensity (LUI index). All variables were present in the $\mathrm{PC} 1$, and all of them were highly correlated with it (Table 3). Thus, the LUI index obtained from the PC1 summarises the information of the five management variables into a single variable.

Overall, the LUI index values ranged from -1.19 to 1.0 and spanned almost uniformly over the whole range (Fig. 1). The LUI index was negative for most of the organic fields (mean \pm standard error), $-0.62 \pm 0.09$; min, -1.19 ; max, 0.18 , whereas the opposite pattern was found for the conventional fields $(0.59 \pm 0.07,-0.01,1.00$; Fig. 1). Thus, the land use intensity was higher in the conventional fields because of the consistent use of chemical weed control measures, the higher proportion of cereal crops in the rotational scheme, the lower crop diversity and the higher nitrogen inputs. In this respect, the LUI index supports the discrete categorisation of the land use intensity in the two differentiated farming systems, organic

Table 3 Principal component and Spearman's correlation analysis of the management variables (see Table 1 for definitions)

\begin{tabular}{lrrrrrr}
\hline & PC1 & PC2 & PC1-cor & WC & CR & CD \\
\hline Nitrogen inputs (N) & -0.28 & 0.07 & -0.85 & 0.73 & 0.61 & -0.54 \\
Weed control (WC) & -0.56 & 0.22 & -0.86 & & 0.73 & -0.62 \\
Cereal ratio (CR) & -0.45 & 0.33 & -0.88 & & 0.93 \\
Crop diversity (CD) & 0.42 & -0.29 & 0.82 & & \\
Seed origin (SO) & -0.47 & -0.87 & 413.00 & & \\
Proportion of variance & 0.64 & 0.23 & & & \\
Cumulative proportion & 0.64 & 0.87 & & & \\
\hline
\end{tabular}

$\mathrm{PC} 1$ and $\mathrm{PC} 2$ are the first two components. PC1-cor is Spearman's correlation analysis between the PC1 and the agricultural variables, and the correlation matrix is between variables

Spearman's correlation analysis between the PC1 and the agricultural variables, and the correlation matrix is between variables. All correlations are significant $(\alpha=0.05)$

${ }^{\mathrm{a}}$ Wilcoxon rank-sum test

$* P<0.07$, marginally significant correlations 
Land Use Intensity Index

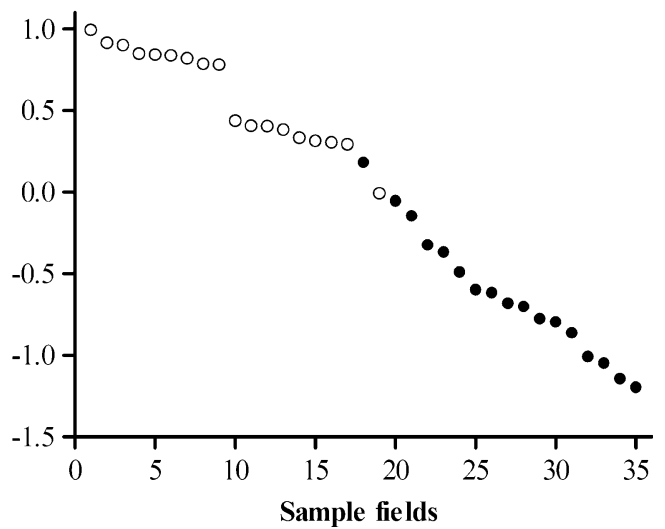

Fig. 1 The land use intensity index for the conventional (empty circles) and organic (black circles) fields, obtained from the scores of the PCA (see Section 2.3)

and conventional, because its values differed significantly between the two groups (Wilcoxon's paired test within site: $V=-14.49, P<0.001)$.

However, there was considerable variation within each group. As a consequence, some fields from the two different farming systems had similar values of the LUI index (Fig. 1), suggesting that the organic and conventional fields could not always be well differentiated by their land use intensity. Therefore, this analysis shows that the land use intensity can vary widely within the farming systems. This result suggests that it would be a gross oversimplification to always equate organic farming with low intensity management or vice versa, although overall land use intensity is lower in organic fields. Similar results were found in the study of Rigby et al. (2001), who analysed the sustainability of organic and conventional horticultural producers. Thus, organic cropping systems per se are not always less intensive than conventional ones. Their land use intensity depends on the agricultural practices performed. In this respect, some authors have identified a kind of conventionalisation of organic farming practices (Darnhofer et al. 2010), i.e., practices that comply with the regulations but not with the principles of organic farming.

When considering the individual farming systems, it became evident that although there was a gradient of land use intensity in both systems, it was wider for the organic fields (percentage of variation in relation to the total range of variation of the LUI index; organic $=63 \%$, conventional $=$ $46 \%$ ). As Table 2 shows, farming practices were more homogenous among the conventional fields than among the organic ones, which is in accordance with data reported by Clough et al. (2007). Conventional fields differed mainly in the total amount of nitrogen fertilisation, whereas the complexity of the rotations, the type and the amount of nitrogen fertilisation and weed control differed greatly among the organic fields.

\subsection{Land use intensity and weed flora}

Altogether, we recorded 72 weed species, 33 (mean species richness per field \pm standard error, $6.5 \pm 1.0, \min =2$, $\max =$ $13)$ in the conventional fields and $66(17 \pm 1.9,10,28)$ in the organic fields. The most frequent species were common ruderal and arable weeds such as Lolium rigidum Gaudin, Polygonum aviculare L. and Papaver rhoeas L., whereas other species (e.g., Hypecoum procumbens L., Kickxia spuria (L.) Dumort and Scandix pecten-veneris L.) appeared in few fields, mainly in the organic ones.

Analysing both farming systems together, the LUI index received the strongest support from statistical analysis for explaining weed species richness, as shown by its AICc value (the lowest) and high selection probability ( $w_{i}$; Table 4). This support was consistent with its confidence intervals, which exclude 0 , and with the high estimated effect (Table 4). Land use intensity is the result of many agricultural practices (Reidsma et al. 2006). Therefore, the assessment of its effects on weed species richness using the LUI index, which integrates the information about many management variables, provides the most accurate results.

Weed control intensity was also a good predictor for explaining weed species richness, based on the $\Delta_{i}$, its selection probability and the confidence intervals. Nitrogen inputs, cereal ratio, the farming system and crop diversity were also suitable predictors of weed species richness, according to their confidence intervals. However, they received weaker support than the LUI index and weed control because of the high $\Delta_{i}$ values $(>7)$ and the low selection probabilities of these variables. In contrast, seed origin was inappropriate for explaining weed species richness (Table 4).

It is worth noting that the LUI index, weed control, nitrogen inputs and cereal ratio all fit the data better than the farming system, which simply splits the data into two non-overlapping groups. Conversely, these variables, apart from distinguishing between organic and conventional farming, encompass the gradient of land use intensity within each farming system. Hence, their accuracy in explaining the observed weed flora is higher. The existence of a land use intensity gradient within organic and conventional management practices can explain for the absence of differences in weed species richness between the two farming systems as reported in some studies (Kleijn et al. 2001; Weibull and Östman 2003; Winfree et al. 2008).

The separate analysis of organic and conventional fields revealed that the suitability of each variable depended on the farming system. The LUI index was the variable with the strongest support for explaining weed species richness 
Table 4 Results of the models testing the effect of land use intensity using the Land Use Intensity index (LUI index), the farming system and the five management variables on weed species richness for all, the organic and the conventional fields

The table indicates the Akaike's Information Criterion corrected value (AICc), the delta AICc $\left(\Delta_{i}\right)$ and the relative importance $\left(w_{i}\right)$ for all the models. It also includes the estimates of the predictors and their $95 \%$ confidence interval (CI). Bold indicates the variables receiving strong support

\begin{tabular}{|c|c|c|c|c|c|}
\hline Predictor & $\mathrm{AICc}$ & $\Delta_{i}$ & $w_{i}$ & Estimate & $\mathrm{CI}$ \\
\hline \multicolumn{6}{|l|}{ All } \\
\hline LUI index & 123.93 & - & 0.56 & -6.28 & $-7.74,4.83$ \\
\hline Weed control & 124.54 & 0.61 & 0.41 & -6.09 & $-7.69,-4.48$ \\
\hline Nitrogen inputs & 131.69 & 7.76 & 0.01 & -5.60 & $-7.50,-3.70$ \\
\hline Cereal ratio & 132.45 & 8.52 & 0.01 & -5.72 & $-7.56,-3.88$ \\
\hline Farming system & 133.56 & 9.64 & 0.00 & -5.28 & $3.40,7.16$ \\
\hline Crop diversity & 138.53 & 14.60 & 0.00 & -4.87 & $-7.11,-2.64$ \\
\hline Seed origin & 148.45 & 24.52 & 0.00 & -2.69 & $-5.52,0.14$ \\
\hline \multicolumn{6}{|l|}{ Organic } \\
\hline LUI index & 57.28 & - & 0.97 & -5.41 & $-7.29,-3.54$ \\
\hline Crop diversity & 66.18 & 8.90 & 0.01 & -4.33 & $-7.26,-1.40$ \\
\hline Weed control & 66.71 & 9.44 & 0.01 & -4.22 & $-7.23,-1.20$ \\
\hline Cereal ratio & 67.05 & 9.78 & 0.01 & -4.14 & $-7.20,-1.07$ \\
\hline Nitrogen inputs & 68.96 & 11.69 & 0.00 & -3.61 & $-6.98,-0.24$ \\
\hline Seed origin & 69.49 & 12.21 & 0.00 & -3.43 & $-6.89,0.03$ \\
\hline \multicolumn{6}{|l|}{ Conventional } \\
\hline Nitrogen inputs & 60.94 & - & 0.71 & -1.98 & $-3.70,-0.25$ \\
\hline Seed origin & 64.76 & 3.82 & 0.10 & -1.01 & $-3.06,1.04$ \\
\hline LUI index & 65.59 & 4.65 & 0.07 & -0.50 & $-2.63,1.63$ \\
\hline Cereal ratio & 65.83 & 4.89 & 0.06 & -0.12 & $-2.27,2.04$ \\
\hline Crop diversity & 65.84 & 4.90 & 0.06 & -0.08 & $-2.23,2.08$ \\
\hline
\end{tabular}

in the organic fields based on the AICc value, the selection probability and the confidence interval. Crop diversity, weed control, cereal ratio and nitrogen inputs were also suitable variables for explaining the variability in weed species richness among the organic fields. However, they were weaker predictors according to the selection probability and the AICc value. Conversely, nitrogen inputs had the lowest AICc value in the conventional fields and were the only variable supported by both the confidence intervals and the selection probability (Table 4; Fig. 2).

The different statistical strengths of these variables between the farming systems may be attributed to two causes. First, although we detected a gradient in the LUI index among the conventional fields, herbicides have a larger impact on weed species richness than the rest of the management variables, which could be the reason that changes in the LUI index were not clearly related to weed species richness in the conventional fields. In contrast, farming practices are generally less intensive in the organic fields. Thus, it is the combination of the management practices, as expressed by the LUI index, which best explained weed species richness. Secondly, nitrogen inputs were higher in the conventional fields than in the organic ones (five times higher on average). The high levels of
Fig. 2 Weed species richness in relationship to the land use intensity index and nitrogen inputs for the conventional (empty circles) and the organic fields (black circles)
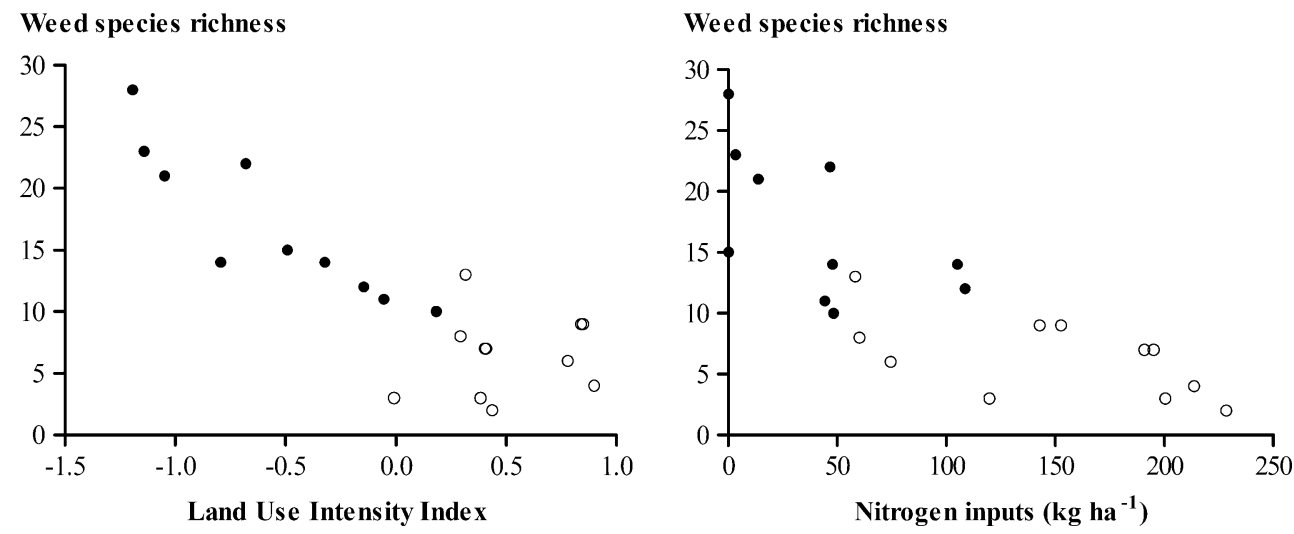
fertilisation could increase the competitive performance of the cereal crop, negatively affecting weed species richness. Several authors have previously reported that the total amount of nitrogen fertilisation has negative consequences on weed diversity (Billeter et al. 2008; Firbank et al. 2008; Kleijn et al. 2009). Thus, the difference in the appropriateness of this parameter between organic and conventional fields may be related to the wider range of nitrogen inputs among the conventional fields. Moreover, the greater suitability of nitrogen inputs for the assessment of weed species richness in the conventional fields, compared with the LUI index, may be a consequence of the low weight attributed by the PCA to this variable in the LUI index (see Table 2). Therefore, the selection of a particular variable to assess land use intensity and its relationship with weed flora should depend on the aim of the study and its context. For instance, in our study, the LUI index focused more on the heterogeneity within the organic fields, whereas the nitrogen inputs were more correlated with the differences in weed diversity among the conventional fields.

\section{Conclusion}

This study proves that the novel index developed here, which integrates information on different agricultural practices into a single variable, is a more suitable approach for measuring land use intensity than the classical organicconventional dichotomy. This study also demonstrates that weed species richness is reduced under intensive land use. The LUI index and also other variables such as weed control intensity and nitrogen input have proven to be more suitable than the farming system for explaining the observed weed species richness.

Acknowledgements We thank the farmers for their collaboration and the members of the Department of Plant Biology (University of Barcelona), especially A. Romero for field and office assistance. We also thank J. Romanyà for his help with the nitrogen input calculations. This research was funded by the Spanish Ministry of Education and Science with a fellowship to the first author and the projects CGL2006-13190-C03-01 and CGL2009-13497-C02-01.

\section{References}

Bates D, Maechler M, Dai B (2008) lme4: Linear mixed-effects models using S4 classes. Version 0.999375-26

Billeter R, Liira J, Bailey D et al (2008) Indicators for biodiversity in agricultural landscapes: a pan-European study. J Appl Ecol 45:141-150. doi:10.1111/j.1365-2664.2007.01393.x

Bockstaller C, Guichard L, Makowski D, Aveline A, Girardin P, Plantureux S (2008) Agri-environmental indicators to assess cropping and farming systems. A review. Agron Sustain Dev 28:139-149. doi:10.1051/agro:2007052
Burnham KP, Anderson DR (2002) Model selection and multimodel inference. A practical information-theoretic approach. Springer, New York

Clough Y, Holzschuh A, Gabriel D, Purtauf T, Kleijn D, Kruess A, Steffan-Dewenter I, Tscharntke T (2007) Alpha and beta diversity of arthropods and plants in organically and conventionally managed wheat fields. J Appl Ecol 44:804-812. doi:10.1111/ j.1365-2664.2007.01294.x

Darnhofer I, Lindenthal T, Bartel-Kratochvil R, Zollitsch W (2010) Conventionalisation of organic farming practices: from structural criteria towards an assessment based on organic principles. A review. Agron Sustain Dev 30:67-81. doi:10.1051/agro/2009011

Decaëns T, Jiménez JJ (2002) Earthworm communities under an agricultural intensification gradient in Colombia. Plant Soil 240:133-143. doi:10.1023/A:1015844610604

R Development Core Team (2008) R: A language and environment for statistical computing. R Foundation for Statistical Computing, Vienna, Austria. ISBN 3-900051-07-0. Available from: http:/ www.R-project.org/

Firbank LG, Petit S, Smart S, Blain A, Fuller RJ (2008) Assessing the impacts of agricultural intensification on biodiversity: a British perspective. Phil Trans R Soc B 363:777-787. doi:10.1098/ rstb.2007.2183

Gibson RH, Pearce S, Morris RJ, Symondson WOC, Memmott J (2007) Plant diversity and land use under organic and conventional agriculture: a whole-farm approach. J Appl Ecol 44:792803. doi:10.1111/j.1365-2664.2007.01292.x

Giller KE, Beare MH, Lavelle P, Izac AMN, Swift MJ (1997) Agricultural intensification, soil biodiversity and agroecosystem function. Appl Soil Ecol 6:3-16. doi:10.1016/S0929-1393(96) 00149-7

Guerrero I, Martínez P, Morales MB, Oñate JJ (2010) Influence of agricultural factors on weed, carabid and bird richness in a Mediterranean cereal cropping system. Agric Ecosyst Environ 138:103-108. doi:10.1016/j.agee.2010.04.006

Herzog F, Steiner B, Bailey D et al (2006) Assessing the intensity of temperate European agriculture at the landscape scale. Eur J Agron 24:165-181. doi:10.1016/j.eja.2005.07.006

Hole DG, Perkins AJ, Wilson JD, Alexander IH, Grice PV, Evans AD (2005) Does organic farming benefit biodiversity? Biol Conserv 122:113-130. doi:10.1016/j.biocon.2004.07.018

Holzner W (1982) Concepts, categories and characteristics of weeds. In: Holzner W, Numata M (eds) Biology and ecology of weeds. Dr W. Junk Publishers, The Hague, pp 3-20

Idescat, Institut d'Estadística de Catalunya (2010) http://www.idescat. cat. Accessed 10 May 2011

Karlen DL, Varvel GE, Bullock DG, Cruse RM (1994) Crop rotations for the 21st century. Adv Agron 53:1-45. doi:10.1016/S00652113(08)60611-2

Kleijn D, Berendse F, Smit R, Gilissen N (2001) Agri-environment schemes do not effectively protect biodiversity in Dutch agricultural landscapes. Nature 413:723-725. doi:10.1038/ 35099540

Kleijn D, Kohler F, Báldi A et al (2009) On the relationship between farmland biodiversity and land-use intensity in Europe. P Roy Soc B-Biol Sci 276:903-909. doi:10.1098/rspb.2008.1509

Lundkvist A (2009) Effects of pre- and post-emergence weed harrowing on annual weeds in peas and spring cereals. Weed Res 49:409-416. doi:10.1016/j.eja.2008.01.001

Mas AH, Dietsch TV (2003) An index of management intensity for coffee agroecosystems to evaluate butterfly species richness. Ecol Appl 13:1491-1501

Matson PA, Parton WJ, Power AG, Swift MJ (1997) Agricultural intensification and ecosystem properties. Science 277:504-509. doi:0.1126/science. 277.5325 .504 
Petit S, Boursault A, Le Guilloux M, Munier-Jolain N, Reboud X (2011) Weeds in agricultural landscapes. A review. Agron Sustain Dev 31:309-317. doi:10.1051/agro/2010020

Reidsma P, Tekelenburg T, van den Berg M, Alkemade R (2006) Impacts of land-use change on biodiversity: an assessment of agricultural biodiversity in the European Union. Agric Ecosyst Environ 114:86-102. doi:10.1016/j.agee.2005.11.026

Rigby D, Woodhouse P, Young T, Burton M (2001) Constructing a farm level indicator of sustainable agricultural practice. Ecol Econ 39:463-478. doi:10.1016/S0921-8009(01)00245-2

Robinson RA, Sutherland WJ (2002) Post-war changes in arable farming and biodiversity in Great Britain. J Appl Ecol 39:157176. doi:10.1046/j.1365-2664.2002.00695.x
Shriar AJ (2000) Agricultural intensity and its measurement in frontier regions. Agrofor Syst 49:301-318. doi:10.1023/A:1006316131781

Stevenson FC, Légère A, Simard RR, Angers DA, Pageau D, Lafond J (1997) Weed species diversity in spring barley varies with crop rotation and tillage, but not with nutrient source. Weed Sci 45:798-806

Weibull AC, Östman Ö (2003) Species composition in agroecosystems: the effect of landscape, habitat, and farm management. Basic Appl Ecol 4:349-361. doi:10.1111/j.1365-2664.2007.01418.x

Winfree R, Williams NM, Gaines H, Ascher JS, Kremen C (2008) Wild bee pollinators provide the majority of crop visitation across land-use gradients in New Jersey and Pennsylvania, USA. J Appl Ecol 45:793-802. doi:10.1111/j.1365-2664.2007.01418.x 